\title{
COMBINING DEMOCRATIC EQUALITY AND LUCK EGALITARIANISM
}

\author{
ASSOCIANDO A IGUALDADE DEMOCRÁTICA E O IGUALITARISMO \\ DA SORTE
}

Lars Lindblom*

lars.lindblom@umu.se

\begin{abstract}
The concept of responsibility plays a crucial part in the debate between proponents of democratic equality, like Rawls, and defenders of luck egalitarianism, such as Dworkin. In this paper it is argued that the two theories can be combined, and that they should be combined to achieve a theory of justice that puts personal responsibility in its proper place. The concept of justice requires two different conceptions. The two theories can be combined because they deal with different problems of justice. They ought to be combined because, first, luck egalitarianism needs a theory of background justice, and second, a theory of justice must supply an answer to the question of just individual allocations, something that is not provided by democratic equality. Democratic equality and luck egalitarianism solve each other's problems. The combined theory will lead to allocations of goods that respect both the difference principle and the envy test.
\end{abstract}

Keywords: Allocative Justice, Democratic Equality, Luck Egalitarianism, Responsibility, Social Justice.

Sumário. O conceito de responsabilidade desempenha um papel crucial no debate entre os defensores da igualdade democrática, como Rawls, e os defensores do igualitarismo da sorte, como Dworkin. Neste artigo, argumenta-se que as duas teorias podem ser associadas para alcançar uma teoria da justiça que coloca a responsabilidade pessoal no seu devido lugar. O conceito de justiça requer duas concepções diferentes. As duas teorias podem ser associadas por lidarem com diferentes problemas sobre a noção de justiça. Elas devem ser associadas porque, em primeiro lugar, o igualitarismo da sorte precisa de uma teoria de fundo da justiça, e em segundo lugar, a teoria da justiça deve fornecer uma resposta à questão da distribuicão individual justa, algo que não é esclarecido pela igualdade democrática. Cada uma das duas teorias, a igualdade democrática e o igualitarismo da sorte, resolve os problemas da outra. A teoria associada levará a uma distribuição de bens que respeita o princípio de diferença e o teste da inveja.

Palavras-chave: Igualdade democrática, Igualitarismo da sorte, Justiça alocativa, Justica Social, Responsabilidade.

* Lecturer, Department of Historical, Religious and Philosophical Studies, Umeå University, Humanisthuset, 10044 Umeå, Sweden. 


\section{o. Introduction}

The notion of responsibility plays a central role in liberal egalitarian political philosophy. The debate between proponents of democratic equality and defenders of luck egalitarianism concerns the appropriate way to hold people responsible for their choices in terms of the theory of justice. The luck egalitarian view is that justice is sensitive to people's choices and that responsibility is therefore essential to the content of the theory of justice, whereas proponents of democratic equality claim that responsibility should not play a role in defining justice. In order to decide which theory best captures the notion of justice, it seems that we need to know where to make the cut between circumstances for which people are and are not responsible.

In this paper, I will argue that we should make not one but two such cuts, and hence that we need two interrelated conceptions of the concept of justice. The theories appear to contradict each other with regards to responsibility, but I will attempt to show that we can and should combine a version of democratic equality and a version luck egalitarianism into a combined view of justice. I will first demonstrate that Rawls's democratic equality view ${ }^{1}$ and Dworkin's luck egalitarianism ${ }^{2}$ can be combined, as they deal with two different questions of justice, at least to the extent that the core conceptions, such as their accounts of responsibility and distributive principles, of the two theories are retained. Rawls's theory is a theory of background justice, and I shall argue that we should interpret Dworkin's luck egalitarianism as a theory of justice in terms of individual allocations. Within this interpretation, the theories answer different questions about justice. The two theories should be combined because we want answers to both questions and because neither theory can answer both questions on its own.

\footnotetext{
${ }^{1}$ The obvious place to start is John Rawls (1971), but see also Rawls (1996) and (2001). Elizabeth S. Anderson defends democratic equality against luck egalitarianism in (1999).

${ }^{2}$ The term "choice egalitarian" probably better captures Dworkin's intentions, but the "luck egalitarian" label has stuck, so I will use it throughout the article. The canonical statement of Dworkin's theory of equality of resources was published in (1981), which was also reprinted along with other papers on equality in (2000). Other important papers that started this tradition are the classics by G.A. Cohen (1989) and Richard Arneson (1989).
} 
This article does not aim to show that both sides of the debate on justice of the last thirty years have been mistaken. Quite the opposite. It aims to develop a position that allows us to say that both sides have been right.

Rawls's difference principle supplies us with a macro outline of the distribution of income in a just society, but it does not say which person should end up at which point in this distribution. But as Dworkin has pointed out, who gets what is a question we want to have answered when we are thinking about justice. On the combined view, holding a person fully responsible for bad option luck in a society in which background justice is in place is to say that it would be just if he or she ends up among the least advantaged in a society that is designed so that the least advantaged are as well off as possible. This is letting responsibility play a role. A further reason for combining the two theories is that if luck egalitarianism is applied against a Rawlsian background, then it is not susceptible to the counterarguments from callousness that have been put forward by Elizabeth Anderson.

This article consists of seven parts, the first of which provides some background on the concept of justice and the value of responsibility, and a discussion on the major role of the latter value in the quest for an appropriate conception of justice in political philosophy. Here I will also introduce the distinction between social and allocative justice, which will help us in combining the two theories. The second section focuses on Rawls's strict egalitarianism 3 and on his views on justice and responsibility. The third section presents Dworkin's criticism of Rawls's theory of justice as fairness and outlines Dworkin's theory of equality of resources. The fourth section is devoted to Anderson's criticism of that theory. The fifth section starts by identifying an impasse. Democratic equality does not include responsibility factors in its criterion of justice, which seems to have the consequence that individual choice plays too little a role, whereas including that value, like luck egalitarianism does, leads to the problems of callousness. I suggest that we could combine Rawls's strict egalitarianism with Dworkin's luck egalitarianism. The sixth section, argues that the two theories should be combined, since they solve each other's problems. The outlines of such

\footnotetext{
${ }^{3}$ I am using the phrase strict egalitarianism in a technical sense that will be explained in the next section.
} 
a combined theory are sketched and some appealing features of such a theory are highlighted. The article ends with some concluding remarks.

\section{Social Preferences, the Accountability Principle, and the Concept of Justice}

Let us start with H.L.A. Hart's (1994, 156-167) distinction between concepts and conceptions. The concept of justice is our pre-theoretical and everyday notion of how goods ought to be distributed. A conception of justice is a theoretical and normative attempt to spell out a coherent and reasonable specification of that concept. 4 This section is devoted to laying the groundwork for the investigation of justice from such a perspective. We will do this with the aid of behavioural economics, in order to get a hold on the concept of justice by means of an empirically grounded and tested approach.

When economists started testing game theory empirically, some surprising results emerged, which will help us to identify the outlines of the concept of justice. In the "ultimatum game", one party proposes a split of a resource and the other party either rejects the proposal and neither party gets anything, or accepts and the resource is split according to the proposal. In this game, proposers tend to offer about $40 \%$ of the total pie, and respondents commonly reject offers below 20\%. In the "dictator game", the respondent does not have the option to reject a proposal. However, the proposers still offer, on average, about 20\%. Standard economic rationality would predict that proposers would offer the lowest possible amount above zero in the first game and nothing in the second. This would guarantee that a rational responder would accept the offer in the ultimatum game, and, of course, in the dictator game a rational player would not consider the other player at all when deciding what split to propose (Camerer 2003). There is a fairly clear pattern in the results, which becomes only becomes clearer the less self interest there is at stake in a distributive choice, and this has led

4 John Rawls uses this distinction in (1971), on page 5, when he is explaining the role of justice, and Ronald Dworkin makes use of it in (1977, 134-136). 
researchers to suspect that there is a structure to our preferences that could explain them. Since the pioneering study of Yaari and Bar-Hillel (1984) in the early eighties, numerous attempts have been made to find this structure in our preferences. 5

One especially promising option is the accountability interpretation of people's social preference for equitable division. The accountability principle says that an individual's entitlement varies in direct proportion to the value of the individual's relevant discretionary variables, but does not hold the individual accountable for the values of exogenous variables (Konow 1996). A discretionary variable in this model is one that is under the control of the individual; often this has to do with choice. An exogenous variable is one that is not under the control of the individual. The principle implies that individuals should get equal shares if they are equally responsible for the outcomes, and that any fair step away from equality must depend on differences in responsibility exercised by the parties. In empirical tests that include production at the stage prior to the split, this model does exceptionally well. ${ }^{6}$ Social science may have gotten a handle on the concept of justice.

Not only does this research accurately predict people's distributive choices, but it also provides a framework in which the most central views on liberal justice can be systematized. Cappelen et al. have proposed such a framework that captures both the central views on justice in political philosophy and the concept of justice as described by the accountability principle. At first glance, the accountability principle might seem like a way of describing luck egalitarianism, but the idea is more general. Strict egalitarians say that there are no relevant discretionary variables, which implies that the distribuendum should be distributed equally. Libertarians believe that all variables are to be considered as discretionary, coercion aside, which implies that there is no room for equality and that individual choices should decide the distribution entirely. There are also two intermediate positions. Choice egalitarians-in other words, luck egalitarians-

\footnotetext{
${ }^{5}$ Among the more influential papers that have attempted explanations in terms of justice are the following studies by Gary E. Bolton and Axel Ockenfels (2000), Ernest Fehr and Klaus M. Schmidt (1999), James Konow (1996), and Gary Charness and Matthew Rabin (2002).

${ }^{6}$ See Konow (2000) for an $\mathrm{R}^{2}$ of 0.983 .
} 
believe that people should only be held responsible for their choices. Meritocrats also hold people responsible for their choices, but they also think that we can be held responsible for our personal characteristics, such as our innate talents. These theories agree on the general outline of justice, but they make different responsibility cuts (Cappelen et al. 2010). The research concerning people's actual fairness ideals shows that people tend to spread out over the four positions (Cappelen et al. 2007). This line of research gives us one way of pinning down the concept of justice, but if we are to find the proper conception of justice, we must engage in normative debate about for what, if anything, we should hold people responsible.

Since the standards views of justice in political philosophy can be categorized in terms of their approach to responsibility, it might seem that if we could locate the correct responsibility cut, we would be able to hone in on a solution to the problem of justice. We could then rather easily move from the concept to the (best) conception of justice. However, finding the right conception of justice is more complicated than it might seem. The answer to the question of what is the best conceptualization of a moral concept depends on the specific moral problem with which we are concerned. There are at least two different types of justice problems (Rawls 2001, 50). On the one hand, allocative justice concerns the way in which we should divide (or, rather, allocate) a given bundle of goods among a given set of individuals, knowing their preferences, needs, and desires. Here we ask, who should get what? This is the typical problem in economic analysis, and most work in experimental economics focuses on questions of allocative justice. On the other hand, debate in political philosophy often concerns the structure of the institutional framework in a just society. This I shall call the question of social justice.7 David Miller explains it as the moral problem that appears when we are within circumstances that satisfy three conditions: first, there is a group of people connected in a framework that distributes benefits and costs; second, there are institutions that are responsible for this distribution so that we can apply principles of justice to them; third, there are ways of changing this institutional structure in accordance with such

\footnotetext{
${ }^{7}$ Rawls $(2001,50)$ calls this distributive justice, but this is terminology seems slightly misleading, since one may say, without misusing ordinary language, that allocative justice also deals with questions of justice in distribution.
} 
principles (Miller 1999, 4-6). Principles of social justice, in this sense, deals with institutional design, and not with the division of bundles of goods. As we shall see below, theories of democratic equality deals with the design of just institution, whereas luck egalitarianism can be understood as concerned with allocative justice.

It makes a world of difference if we are concerned with justice in single economic transaction, as in allocative justice, or with the institutional design of a just society, as in social justice. Even if we could solve the problem of justice in the wider case of social justice, it does not necessarily follow that we would also have a solution appropriate for the narrower case of piecemeal transactions. Each problem must be investigated on its own terms, and might need its own conception of the general concept of justice. Furthermore, there may be interrelationships between the two levels, which should be taken into account when designing the different conceptions. The issue of personal responsibility plays a major part in exemplifying these points in the remainder of this paper. The intuition that I will investigate is if the concept of justice needs two different conceptions for the problems of allocative and social justice.

\section{Democratic Equality}

John Rawls's theory of democratic equality is an attempt to answer this question:

[h]ow are the institutions of the basic structure to be regulated as one unified scheme of institutions so that a fair, efficient, and productive system of social cooperation can be maintained over time, from one generation to the next? $(2001,50)$.

The goal is to set up the institutions of the basic structure-the main political and social institutions of society-so that we can say that the distribution of rights, opportunities, and resources is fair, regardless of exactly who gets what, or, to put it another way, regardless of the resulting allocation between actual persons. This is pure procedural background justice, and a clear-cut example of a theory of social justice.

The idea is that a theory of justice should start with institutional background justice, because the basic structure plays such an important role in how people's 
lives turn out and in what choices they make. Outcomes for people in real life do not depend solely on the choices that they make. Both cultural backgrounds and innate capabilities play roles in determining the central responsibility variables of choice and talent. What part should these be allowed to play in the conception of social justice? Rawls's answer is clear: none. "No one deserves his greater natural capacity nor merits a more favourable starting place in society" (Rawls 1971, 102). In other words, responsibility for these factors has no place in the design of a just basic structure, and, hence, not in our conception of justice. In Cappelen et al's terminology, Rawls is a strict egalitarian, because he holds that there are only exogenous variables at stake in justice. Responsibility comes into play for Rawls after we have set up the basic structure justly. Background justice concerns the fair background conditions for responsible choice. The idea is that when background justice is achieved, "[i]t is left to the citizens as free and equal persons, secure in their rights and liberties and able to take charge of their own life, to avail themselves of the opportunities guaranteed to all on a fair basis" (2001, 171).

How, then, do Rawls's two principles of justice deal with the impact of culture and innate talent? The second of his two famous principles consists of two sub-parts: fair equality of opportunity and the difference principle. Fair equality of opportunity says that not only should positions in society be open to all, but all should also have a fair chance of attaining them. "The expectations [of culture and achievement] of those with the same abilities and aspirations should not be affected by their social class" $(1971,73)$. When this principle is implemented, individuals' choices are no longer determined by the contingencies of the sociocultural background. This creates the starting points from which individuals can be held responsible, since one very important reason for not holding people responsible is removed. However, we may assume that even if aspirations are functions of culture, we could not reach all the way to equality of aspiration as long as the institution of the family remains (possibly forever), and we probably have at least some abilities that are innate. These facts are part of the reason that we also need the difference principle. If these contingencies of nature cannot or should not be eradicated, there is another solution. We could try to arrange the basic structure so that these contingencies work for the benefit of those least advantaged (Rawls 1971, 63-65). When this is the case, those who gain more, 
presumably those with more innate talent, do so in a way that is to the most advantage for the least talented.

The difference principle is generally taken to include the distribution of income and wealth only, but correctly understood, says Rawls, it also implies that there should be a safety net, including medical care for all. The difference principle underwrites equality of opportunity and equal citizenship; in order to function as an equal citizen one needs health care at various stages in life, and therefore the state is obliged to provide such care. This means that the difference principle implies a social minimum (2001, 173-176). When the two principles are in effect, there is a place for the notions of responsibility and therefore desert, because choice is not determined by factors irrelevant to justice. But Rawls points out that "this sense of desert presupposes the existence of the cooperative scheme; it is irrelevant to the question whether in the first place the scheme is to be designed in accordance with the difference principle or some other criterion" (1971, 103). Responsibility ascriptions have their place within the basic structure.

\section{Luck Egalitarianism}

It is sometimes said that Ronald Dworkin revived the egalitarian cause by incorporating the idea of responsibility directly into the theory of equality (Cf. Cohen 1989, 933). In order to see how this was done, we now turn to Dworkin's theory of equality of resources. This theory is the standard example of luck egalitarianism. A good way to start is to look into the faults Dworkin finds with Rawls's conception of justice. The first basic problem is that it is not fine-tuned enough. The difference principle works to improve the lot of the least advantaged group in society. Equality, however, says Dworkin "is in principle a matter of individual right rather than group disposition" $(1981,340)$. Equality of resources is an attempt "to provide a description [of] equality of resources person by person, and the considerations of each person's history that affect what he should have, in the name of equality, do not include his membership in any economic class" (1981, 340). The second problem concerns responsibility. Rawls fails to take seriously individual history and choice. By invoking the difference principle, Rawls mistakenly "supposes that flat equality in primary goods, without regard 
to differences in ambition, taste, and occupation, or to differences in consumption, let alone differences in physical condition or handicap, is basic or true equality" (1981, 343).

In other words, egalitarian justice is achieved when individual entitlements, where appropriate, are based on individual choice. Where Rawls famously starts with a contract, Dworkin starts with an auction. The distribution of goods in a society is just when it mimics the outcome of this auction-based thought experiment. A group of shipwrecked people comes ashore on a deserted island full of resources. They all agree that no one has a prior claim to the resources, i.e., there are no relevant discretionary variables. They decide to hold a Walrasian auction, where each gets an equal amount of markers to use in bidding for the resources he or she individually prefers. They apply the so-called envy test to ensure that equality is preserved. This idea says that a justified division is achieved when no one prefers anybody else's bundle of goods. The test is satisfied through the auction, because if a person envies someone else's bundle, he or she is free to bid for it. In this way, every person bears the cost of his or her choice of lifestyle, while equality is preserved. Every immigrant is responsible for the use he or she makes of the markers he or she has been dealt at the start of the auction. The measure of equality of resources is then the allocation that would result from an auction in which all participating parties have equal resources at the start. This is how justice can be individualized.

However, after some time on the island, some people will have worked more than others, some will have fallen sick, others will have been lucky in business, and, of course, accidents will happen. When such things have happened, the envy test will no longer be satisfied. It is here that Dworkin's famous distinction between brute and option luck comes into play. Option luck has to do with how deliberate gambles turn out, for instance, if a person decides to play the stock market and loses his or her money-or, for that matter, grows very wealthy. Brute luck concerns plain bad unforeseeable luck, e.g., being hit by a meteorite, or in the case of brute good luck, finding a lost treasure. Insurance provides a bridge between brute and option luck. A person who prefers to play it safe can buy insurance, while risk-takers can choose to go without a safety net. If insurance is available, then brute luck is converted into option luck. Thus, the envy test can 
still be satisfied. In setting up the auction, we "have already decided that people should pay the price of the life they have decided to lead...[s]o we have no reason to object...to a result in which those who decline to gamble have less than some of those who do not" $(1981,294)$. We should neither object to the fact that some people gamble and win nor to outcomes where they have gambled and lost. Redistribution from winners to losers is ruled out, because this would mean that the winner would be made to bear the cost of the life choices of the losers.

Dworkin makes one further distinction to clarify for what people are responsible. The goal of equality of resources is that holdings should be ambitionsensitive, but not endowment-sensitive. The allocation of resources must be sensitive to the choices that people make, with regard to, for example, savings, consumption, and production, but it must not be sensitive to exogenous variables, such as talent, handicaps or brute luck. In order to spell out this notion, Dworkin develops a thought experiment where the parties choose insurance packages against such exogenous bad luck. Justice, then, demands that the distribution of resources mimics the outcome of this hypothetical insurance market. ${ }^{8}$ In short, a distribution of goods is just if it could have been achieved from a starting point of equal shares by trade, holding people responsible for ambition and option luck while compensating for bad brute luck and equalizing the result of unequal endowments. In conclusion, Dworkin's theory of justice answers questions like who should get what; it is a conception of justice that deals with allocative justice. It solves the two problems that Dworkin finds with Rawls's theory by incorporating the value of responsibility in the conception of justice.

\section{Anderson and the Problems of Luck Egalitarianism}

We turn now to perhaps the most important critic of luck egalitarianism, Elizabeth Anderson (1999). She finds many faults with this kind of theory, but here we will concentrate on four aspects of it that bring the question of responsibility most clearly into focus. The first is what Anderson calls the

\footnotetext{
${ }^{8}$ Dworkin discusses this hypothetical insurance scheme to handle the issue of handicaps extensively. However, in what follows it will play a minor role, because John Roemer has conclusively shown that Dworkin's thought experiment does not produce the conclusions for which he is looking; see Roemer (1996, chapter 7). The parties behind this veil of ignorance would allocate more resources to those who are most able to use them efficiently in the pursuit of utility. In other words, the healthy and vigorous would get the money.
} 
abandonment of negligent victims. If only bad brute luck should be compensated, it follows that the results of bad option luck are of no concern to justice. This implies that it would be just that an ambulance passed by a dying person who has made a deliberate decision not to buy insurance. The second, and similar, problem can be called the abandonment of the prudent. A person who is struck by several incidents of bad option luck may end up in a situation in which he or she is unable to afford insurance. It might be more prudent to feed one's children than to pay the insurance bill. Such a person can have made all of the reasonable choices and still end up uninsured. If this person finds himself or herself in the traffic accident above, it is just, according to the luck egalitarian view of justice that the ambulance does not stop to help him or her. Both of these problems are related to the third problem: the lack of a safety net. There is something counterintuitive about a theory of justice in which, even if only in principle, the fact that some people have absolutely nothing is considered just. There is in principle no limit to how low one can fall in a society governed by such principles. The final problem we will discuss goes under the heading of the vulnerability of dependent caretakers. This has to do with the traditional way to rear children: father works and mother tends the children. The difficulty for luck egalitarianism is that women, being no less talented than men but choosing to stay home to care for their children, will not make much money for themselves. Apparently, they make a lifestyle choice of being dependent on their spouses, and this dependency comes out as entirely just. For these reasons, Anderson presents the following indictment of Dworkin's view of justice:

The fact that these evils are the product of voluntary choices hardly justifies them: free choice within a set of options does not justify the set of options itself. In focussing on correcting the supposed injustices of nature, luck egalitarians have forgotten that the primary subject of justice is the institutional arrangements that generate people's opportunities over time (1999, 308-309).

Luck egalitarianism seems to have some severe drawbacks when conceived as a conception of social justice. How does Rawls's theory of democratic equality handle these four problems?9 Let us start with the vulnerability of dependent caretakers. From a Rawlsian perspective, this is first and foremost a question of

\footnotetext{
${ }^{9}$ There are clear similarities between the views of Rawls and Anderson, but Anderson prefers Sen's notion of capabilities to primary social goods and also seems to have more republican leanings than Rawls. Therefore, it makes sense to ask this question about Rawls's view, even though both writers position themselves in the democratic-equality camp.
} 
fair equality of opportunity. Life choices should be made against a background where positions are open to all, and everybody should have a fair chance of attaining those positions. That this is not the case becomes obvious when we look at the fact that it is predominantly women who are caretakers in any society we care to investigate. If we are to take fair equality of opportunity seriously, we should strive to create a society in which the choice of becoming a caretaker does not depend on cultural preconceptions of gender. If we could say, which we cannot, under present circumstances, that it is a solely a personal choice to become a homemaker, then we could also consider this problem solved. However, doing so would miss an important part of the complaint, namely that women become economically dependent on men. We can deal with that issue while discussing the abandonment problems and the lack of a safety net.

As we have seen above, the difference principle implies a social minimum, including medical care, which solves the problem of the lack of a safety net by ensuring that there is a limit to how low one can fall in a just society. This kind of safety net guarantees that the ambulance passes by neither the negligent nor the prudent, because it includes an assured level of health care. This also solves both abandonment problems, since people are afforded health care regardless of their responsibility characteristics. Moreover, the difference principle guarantees each person a basic minimum income. If equal basic liberty, fair equality of opportunity, and the difference principle are in effect, we can say that caretakers have all the liberties of citizens, have made the free choice to become caretakers against a full background of options, and are guaranteed an income determined by the difference principle. Men and women are equal citizens, and consequently, are guaranteed individual incomes. Hence, democratic equality can solve all four of luck egalitarianism's problems.

\section{How Democratic Equality and Luck Egalitarianism Could Be Combined}

We seem to have come full circle. Including responsibility and solving the problem of fine-grainedness with Rawls's conception of justice lead to some troubling difficulties. Not including responsibility leads to the Anderson 
problems. How do we proceed from this impasse? First of all, we need to identify where exactly the problems lie. For this purpose, it is instructive to compare democratic equality with the envy test.

The envy test can be applied to any background structure where property rights are guaranteed. Consider a caste system, in which beliefs are widespread that some group in society should do the menial tasks and some other group has a claim to high-ranking positions and where the educational backgrounds of the citizens reflect this. When equal assets have been allocated and trade has taken place, an envy-free distribution of goods will be in place. But this distribution will risk mimicking the caste ideal. If people believe that they are not entitled to positions of power and prestige, they will not pursue such positions. They will not invest in the kind education necessary to move up or in business ventures that would provide advantage. The members of the upper caste will occupy the positions of wealth and power. The lower castes will end up in society's lower positions. The envy test misses this aspect of responsibility, and must be complemented with an account of background justice.

Should luck egalitarianism then be rejected? No, it should be understood as a conception of allocative justice. Since luck egalitarianism is silent on background justice, there will be no contradiction or incoherency in appending a conception of social justice to that theory. As a theory of social justice, we could prefer the Rawlsian conception, but this does not imply that democratic equality is helpful to, or even appropriate for, allocative justice. We must also consider what allocative decisions we should make when background justice has been implemented.

Anderson points out that the difference between democratic equality and luck egalitarianism is that the former envisions justice as a social relationship, while the latter views it as a pattern of distribution. The former aims to secure the social conditions of freedom for all. The goal of the latter is to achieve a just allocation of resources. Democratic justice looks at distributive issues through the lens of considering the effect on people's standings as equal citizens. Often, according to Anderson, "the weight of an interest can be determined by considering the impact on a person's standing as an equal in society" (1999, 332). However, there are cases "where the concepts of equal standing and respect don't 
yield a determinate answer to how capabilities should be ranked, the ranking may legitimately be left up to democratic legislation" (1999, 332). As we have seen above, Rawls leaves it up to free and equal citizens to take charge of their lives after background justice is implemented; this also implies that social justice does not pronounce on every question of fairness. Anderson says that a democracy should promote the common good, but the question is then how this good is to be understood, if democratic equality does not yield a determinate answer. It is clearly true that there is room for democratic decisions here, but should we also believe that justice is quiet on the design of the policy that will result? Surely it is not the case that anything goes. Presumably, we should allocate fairly. The problem for democratic justice is that is not a theory of allocative justice.

To illustrate, I will discuss two areas where the problem of allocation appears: wages and the regulation of traffic. First, let us look at how wages should be set. Anderson says that one thing that is owed to equal citizens is "the right to receive fair value for one's labor" (1999, 318). Can Rawlsian background justice give an answer to the question of fair wages? It seems not, since the principle that governs the distribution of income in society deals with the distribution between groups. The difference principle points to a specific shape of the curve of distribution of resources in society, but it is silent on the question of whether or not the pay people receive in a society that has implemented that curve is fair. When the difference principle has been applied, it is still possible that within the given range, individuals have wages different from what would be just. We cannot use the two Rawlsian principles of justice to analyze this question, because it is not a problem concerning the background of transactions, but a question of justice in transactions. Democratic equality is silent on such problems. Of course, democratic equality will influence what the distributions in such cases will be, but that is because it defines the background for transactions, not because it is a theory which is devised to determine what such outcomes should be. Moreover, we expect wages to take responsibility factors, such as ambition, into account. A person who works more hours, or just works harder, should get more money in return. When background justice is in effect, we would want an allocative principle of justice that takes ambition into account. These are intuitions that are in line with the results we have seen in the experiments in empirical game theory. Democratic equality is neither individualized nor ambition-sensitive, and cannot 
be applied to such problems. What was a virtue in social justice becomes a vice in allocative justice. Moreover, this suggests that luck egalitarianism is a plausible candidate for a conception of allocative justice.

It might be thought that this is a problem particular to the economic sphere, but it also affects political issues proper. Assuming that Rawlsian background justice has been implemented, a problem of externalities can serve as an example. Say that a city is experiencing traffic congestion and needs a solution to this problem. The citizens of the city decide to implement a system in which drivers must pay a fixed sum to enter and exit the city. The system would, therefore, hold people responsible for choosing to use their cars. This would presumably cause people with low incomes to decrease their driving the most, while the richer segments of society would make only small adjustments to their driving habits. Would this be just? If we assume the responsibility cut that Rawls made when he developed his theory of justice, it seems that such a policy would come out as unjust. In that case, we are told not to hold people responsible for their choices. This makes strict equality the obvious criterion of justice. However, to make this responsibility cut when we already have assumed background justice would be a strange maneuver. We have implemented a theory of background justice, the purpose of which is to ensure that everyone can develop and exercise responsibility. If we do not hold people responsible for their choices at this point, it would be clear that we are not taking responsibility at all seriously. Therefore, we should look for a theory that says that it is just for those who drive in the city to bear the costs of creating a sustainable traffic situation. ${ }^{10}$ Again, this suggests that we should look in the direction of luck egalitarianism for a plausible conception of allocative justice.

Democratic equality is best understood as a conception of social justice, whereas luck egalitarianism is a very plausible candidate for the conception of allocative justice. Democratic equality is silent on issues of allocative justice, and luck egalitarianism does not deal with social justice. This is why democratic

\footnotetext{
${ }^{10}$ Obviously there might come a point at which background justice is undermined by this policy. If this is the case, social justice ought to take precedence. I will return to the question of precedence below.
} 
equality and luck egalitarianism can be coherently combined. They deal with different problems.

\section{Why Democratic Equality and Luck Egalitarianism Should Be Combined}

Even if we find that we can combine these two conceptions of justice in one theory of justice, we also need to handle the separate question of why we should go for such a combination. If we look at this question from a Rawlsian perspective, we find that we need to complement the two principles with a conception of allocative justice, that it would be incoherent to argue against the value of responsibility within well-ordered societies, and that we need an allocative principle that is individualized and responsibility-sensitive. The Rawlsian needs to respond to Dworkin's critique. If we instead start from luck egalitarianism, we find ourselves in the position that we need to complement that theory with a conception of background justice, which defines the property rights that the envy test takes for granted and that solves the Anderson problems. The first answer, then, is that the two conceptions solve each other's problem.

We find that that the proponents of democratic equality should be looking for an idea of allocative justice that is individualized and ambition-sensitive, and we are reminded that we had settled for democratic equality as a conception of social justice without having replied to Dworkin's criticisms of Rawls. The first reply should be that democratic equality is silent on the question of allocative justice. It is, in fact, compatible with any number of conceptions of fairness in allocation. It does not say who should get what, but rather talks about the fair background conditions for allocative decisions. The second reply should be to admit that democratic equality is incomplete as a theory of justice if it cannot advise at all on questions of allocative justice. The proponent of democratic equality should, then, welcome the application of luck egalitarianism to problems of allocative justice within societies where social justice is in effect. They ought to welcome a theory that is fine-grained and committed to the view that considerations of responsibility should play a role when fair background conditions are substituted for the natural and social lotteries. By accepting the 
combined view, the Rawlsian gains a way of responding to Dworkin's criticism, without having to give up any part of his or her conception of social justice.

It is natural to think of luck egalitarianism as a conception of social justice. However, all the basic intuitions can be retained, even if we, instead, decide to conceive of it as a conception of allocative justice instead. Allocations will still be ambition-sensitive, but not endowment sensitive, even if the allocations are constrained by the difference principle and fair equality of opportunity. Furthermore, allocations can be fine-grained against any backdrop. In a picture, luck egalitarianism says that we should be held individually responsible for how we approach lotteries; it does not say anything about what the structure of the prizes in the lottery should be. This is how the combined view can solve the four Anderson problems, without compromising the core values of luck egalitarianism. The difference principle solves the problems of callousness, by setting up a minimum level of welfare that no one can fall below. It defines the prize structure. Holding people responsible, applying luck egalitarianism, against this background means that the reckless will have to accept to end up among the least advantaged. Now, luck egalitarians could insist on their theory being understood as a theory of social justice, but this would just mean that the least attractive parts of the theory would be retained, without any clear offsetting gains. We have seen that the combined view is ambition sensitive, while avoiding the problems of callousness, whereas luck egalitarianism has the implication that holding people responsible means that, e.g., the reckless should have absolutely nothing. It is hard to see why this should be an essential aspect of the position. This in turn makes it hard to so what could be gained by insisting that luck egalitarianism should be interpreted as a theory of social justice. Furthermore, it is hard to see what a luck egalitarian could have against fair equality of opportunity. Inequalities in opportunities might even seem to fall under the category of endowment inequality. Democratic equality solves Anderson's four problems, and by applying luck egalitarianism within societies that have implemented social justice, we can also, and at the same time, solve the two problems that Dworkin finds with Rawls. In order to solve the problems of democratic equality, we need luck egalitarianism, and vice versa. The solution to the impasse is, then, to combine democratic equality and luck egalitarianism. 
In order to get a clearer view of how this theory - let's call it the combined view - would work, let us revisit Dworkin's island. The problem faced by its shipwrecked inhabitants is how they should go about dividing a bundle of goods among a group of individuals, knowing their preferences, needs, and desires. If these Robinsons had instead been washed up on an island with a Rawlsian basic structure somehow in place, they could use the same auction mechanism to decide exactly which person would get what resource. They would need a conception of justice that is individualized, that takes people as they are, and that considers responsibility. This is also why they cannot use Rawls's strict egalitarianism to solve their allocative problem. If the background institutions necessary for people to achieve equal power to develop and exercise moral responsibility have been successfully implemented, then it seems unreasonable to again insist on a principle of justice that does not hold people responsible for their choices.

As second way of understanding the question why should democratic equality and luck egalitarianism be combined, would be to take it to mean, why not instead meritocracy or libertarianism? These are the two other conceptions of justice in the Cappelen et al. model. Let us start with asking why not meritocracy? One could think that if democratic justice in effect, fair equality has been applied and the value of responsibility is applicable, then it would only be reasonable to hold people responsible for their talents, and not only for their choices. However, we should remember that one of the reasons that we need the difference principle is that inequalities due to innate talent must be alleviated, since the natural lottery cannot be stopped completely. The difference principle assuages the inequalities that result from differences in talents, it does not eradicate them. Any difference in innate talent must be a result of the natural lottery; otherwise fair equality of opportunity would have equalized it. Social justice does not make innate differences in talent fair. Therefore, meritocracy should not take the place of luck egalitarianism.

We should also prefer luck egalitarianism to libertarianism as the conception of allocative justice. The reason for this has to do with the problem of determining to what degree different individuals are responsible for surplus produced in collective ventures, such as firms. Anderson points out that the "the 
productivity of a worker in a specific role depends not only on her own efforts, but on other people performing their roles in the division of labor. Michael Jordan could not make so many baskets if no one kept the basketball court swept clean" $(1999,322)$. The result of production cannot be fully traced back to the responsible actions of any given person. The surplus has been produced collectively. Exactly how many baskets would Michael Jordan have made on littered courts? Possibly quite a few, but surely fewer than he actually managed. This suggests that if the results of exogenous variables should be equalized, then wages should be equal within the firm to the degree that the result of the firm is not traceable to the effort of given individuals. ${ }^{11}$

Basically, then, these two other conceptions get responsibility wrong. In the case of libertarianism, this conception has no material to work with when there are no identifiable personal responsibility characteristics. Meritocracy does still give the natural lottery too much sway. The second answer, then, to the question of why luck egalitarianism and democratic equality should be combined, is that a combination that includes meritocracy or libertarianism would still have drawbacks that the marriage between democratic equality and luck egalitarianism would not have.

If we opt for the combined view, we would then simultaneously hold two different conceptions of the concept of justice as true. Since they deal with different problems there this would involve no theoretical contradiction. This is why the can solve each other's problems. However, there would be conflicts in practice, when the accumulative effects of holding people responsible in too many areas lead to violations of the difference principle, as might be the case in the earlier road-toll example. ${ }^{12}$ In such cases, social justice should take precedence over allocative justice, since allowing our concerns (based on considerations for justice) about holding people responsible to undermine the preconditions for holding people responsible is getting things backwards. We need to have social justice in effect, in order to be able to apply our conception of allocative justice

\footnotetext{
${ }^{11}$ Or, perhaps, if we want to add some efficiency considerations, the gains should be shared according to the demands of a local difference principle.

${ }^{12}$ Such conflicts show that democratic equality and luck egalitarianism sometimes affect the same thing, but not that they are about the same things. That principles of beneficence and esthetics may come into conflict over whether to set fire to a painting to keep a sick child warm does not show that they concern that same value problem.
} 
properly. Democratic equality fixes the property rights that the envy test takes as its starting point. Giving luck egalitarianism priority would undermine democratic equality, whereas the opposite ordering allows us to maintain the insights of the former theory while avoiding its drawbacks. Therefore, implementing a basic structure governed by the two principles should be given priority over the achievement of allocative justice.

\section{Concluding Remarks}

This paper has examined the idea that the concept of justice should be conceptualized differently for the problems of allocative and social justice. I hope to have shown that there is a natural way to combine the Rawlsian intuition that we should not be held accountable for the type of society into which we are born and the Dworkinian intuition that justice should be individualized and choicesensitive. The same underlying concept of justice may be able to explain both intuitions. The question of social justice and that of allocative justice will have very different answers. Democratic equality and luck egalitarianism are two different conceptions of justice and are best interpreted as having different areas of application. We should make two responsibility cuts.

I have suggested that we should be both democratic and luck egalitarians, in (perhaps even lexical) order, because we need to consider both social and allocative justice. To do this, we must interpret luck egalitarianism not as a theory of social justice, but as a theory with the more narrow scope of just allocations. This is contrary to most standard readings of Dworkin's theory, but it is consistent with the justificatory story he presents. Furthermore, such a combination solves difficulties with both positions without compromising their core insights. Rawlsian justice solves the four problems of luck egalitarianism that we have discussed by providing fair equality of opportunity and by applying the difference principle. Luck egalitarianism solves the two major problems that Dworkin found in Rawls's arguments. It gives us a way to achieve justified ambition-sensitive individual allocations against a fair background. It is not sensible to hold people responsible before a social structure that can sustain responsibility is in place. When social justice is implemented, the background structure needed to create 
responsible citizens is in place, and the difference principle will have defined what "equal shares" mean in a given society. It would be unreasonable to say that people are responsible and then refuse to hold them responsible. Therefore, we should be luck egalitarians within democratic egalitarian societies. The general liberal egalitarian need not choose between luck egalitarianism and democratic equality.

\section{Acknowledgements}

I would like to thank Alexander Cappelen, Bertil Tungodden, James Konow, Mikael Dubois, Kalle Grill, Niklas Möller, Sara Belfrage, Per Wikman Svahn, Isaiah O'Rear, Helen Frowe and Sven Ove Hansson for questions and suggestions. Special thanks to Marcus Widengren and Luciana Widengren for invaluable help. In the context of combining the different yet similar I must also thank Lotta Lindblom.

\section{References}

Anderson ES (1999) What Is the Point of Equality, Ethics 109:287-337 http://www.journals.uchicago.edu/doi/abs/10.1086/233897?journalCode=et

Arneson R (1989) Equality and Equal Opportunity for Welfare. Philosophical Studies 56:77-93 https://link.springer.com/article/10.1007\%2FBFo0646210?LI=true

Bolton GE, Ockenfels A (2000) ERC: A Theory of Equity, Reciprocity, and Competition. American Economic Review 90:166-93 https://www.aeaweb.org/articles?id=10.1257/aer.90.1.166

Camerer C (2003) Behavioral Game Theory: Experiments in Strategic Interaction. Princeton University Press, Princeton https://books.google.se/books?id=o7iRQTOeoAoC\&printsec=frontcover\&hl=sv \&source=gbs_ge_summary_r\&cad $=0 \# \mathrm{v}=$ onepage $\& q \& \mathrm{f}=$ false 
Cappelen A, Hole AD, Sørensen EØ, Tungodden B (2007) The Pluralism of Fairness Ideals: an Experimental Approach. American Economic Review 97:818-827 https://www.aeaweb.org/articles?id=10.1257/aer.97.3.818

Cappelen A, Erik. Sørensen EØ, Tungodden B (2010) Responsibility for what? Fairness and individual responsibility. European Economic Review 54: 429-441

http://www.sciencedirect.com/science/article/pii/So014292109000890

Charness G, Rabin M (2002) Understanding Social Preferences with Simple Tests. Quarterly Journal of Economics 117:817-869 https://academic.oup.com/qje/article/117/3/817/1933015/UnderstandingSocial-Preferences-with-Simple-Tests

Cohen GA (1989) On the Currency of Egalitarian Justice. Ethics 99:906944

http://www.journals.uchicago.edu/doi/abs/10.1086/293126?journalCode=et

Dworkin R (1977) Taking Rights Seriously. Duckworth, London https://books.google.se/books?id=HuwatdQKhgC\&printsec $=$ frontcover\&hl=sv\&source=gbs_ge_summary_r\&cad $=\mathrm{O} \# \mathrm{v}=$ onepage $\& \mathrm{q} \& \mathrm{f}=$ false

Dworkin R (1981) What is equality? Part 2: equality of resources. Philosophy and Public Affairs 10:283-345 http://www.jstor.org./stable/2265047

Dworkin R (2000) Sovereign Virtue - The Theory and Practice of Equality. Harvard University Press, Cambridge https://books.google.se/books?id=SIOPnqu3f5kC\&printsec=frontcover\&hl=sv \&source=gbs_ge_summary_r\&cad $=0 \# \mathrm{v}=$ onepage\&q\&f $=$ false

Fehr E, Schmidt KM (1999) A Theory of Fairness, Competition, and Cooperation. Quarterly Journal of Economics 114:817-868 https://academic.oup.com/qje/article/114/3/817/1848113/A-Theory-ofFairness-Competition-and-Cooperation

Hart HLA (1994) The Concept of Law, 2nd edition. Clarendon Press, Oxford 
https://books.google.se/books?id=hCoUDAAAQBAJ\&printsec=frontcover\&hl= sv\&source=gbs_ge_summary_r\&cad $=0 \# v=$ onepage $\& q \& f=$ false

Konow J (1996) A Positive Theory of Economic Fairness. Journal of Economic Behavior and Organization 31:13-35 http://www.sciencedirect.com/science/article/pii/So1672681960o8621?via\%3 Dihub

Konow J (2000) Fair Shares: Accountability and Cognitive Dissonance in Allocation Decisions. American Economic Review 90:1072-1091 https://www.aeaweb.org/articles?id=10.1257/aer.90.4.1072

Miller D (1999) Principles of Social Justice. Harvard University Press, Cambridge

https://books.google.se/books?id=y2wMzJtEZ_8C\&printsec=frontcover\&hl=sv \&source=gbs_ge_summary_r\&cad $=0 \# \mathrm{v}=$ onepage $\& q \& \mathrm{f}=$ false

Rawls J (1971) A Theory of Justice. Oxford University Press, Oxford https://books.google.se/books?id=kvpby7HtAeoC\&printsec $=$ frontcover\&hl=sv \&source=gbs_ge_summary_r\&cad $=0 \# \mathrm{v}=$ onepage\&q\&f=false

Rawls J (1996) Political Liberalism, 2nd edition. Columbia University Press, New York https://books.google.se/books?id=vXGZRYCkaNsC\&printsec=frontcover\&hl=s $\mathrm{v} \&$ source $=g b s \_g e \_s u m m a r y \_r \& c a d=0 \# v=$ onepage\&q\&f=false

Rawls J (2001) Justice as Fairness: A Restatement. The Belknap Press of Harvard University Press, Cambridge https://books.google.se/books?id=AjrXZIlbK1cC\&printsec=frontcover\&hl=sv\& source $=g b s \_g e \_s u m m a r y \_r \& c a d=0 \# v=$ onepage\&q\&f=false

Roemer JE (1996) Theories of Distributive Justice. Harvard University Press, Cambridge https://books.google.se/books?id=qQkX24xj9akC\&printsec $=$ frontcover\&hl=sv \&source=gbs_ge_summary_r\&cad $=0 \# \mathrm{v}=$ onepage $\& q \& \mathrm{f}=$ false

Yaari ME, Bar-Hillel M (1984) On Dividing Justly. Social Choice and Welfare 1:1-24 https://link.springer.com/article/10.1007\%2FBFo0297056?LI=true 